Gut, 1983, 24, 284-287

\title{
Management of enterocutaneous fistulae in Crohn's disease
}

\author{
P C HAWKER, J C GIVEL, M R B KEIGHLEY, \\ J ALEXANDER-WILLIAMS, AND R N ALLAN
}

From the Gastroenterology Unit, General Hospital, Birmingham

SUMmARY The outcome among 39 patients with enterocutaneous fistulae complicating Crohn's disease has been reviewed. The patients were considered in two groups: (1) no disease - all were early postoperative fistulae $(n=9) ;(2)$ active disease (i) without abscess formation $(n=16)$, (ii) with abscess formation $(n=14)$. Postoperative fistulae with no evidence of active Crohn's disease healed spontaneously. Fistulae in the presence of active disease did not heal even with prolonged medical management. The only effective treatment was excision of the diseased segment from which the fistulae arose and any distal obstruction. None of the fistulae closed surgically has recurred.

The management of enterocutaneous fistulae in Crohn's disease is still debated. Earlier studies ${ }^{12}$ recommended early surgical resection, while others have advocated medical management including total parenteral nutrition. ${ }^{3-5}$

We have reviewed our experience of 39 patients (17 men) with 40 enterocutaneous fistulae seen in this unit between January 1970 and December 1980 to provide guidelines for the management of enterocutaneous fistulae in Crohn's disease. The mean age at diagnosis of fistula was 39.2 years (range 17-70 years) with a mean interval of 9.5 years (range $0-33$ years) from the initial diagnosis of Crohn's disease.

One patient who will not be considered further developed five separate enterocutaneous fistulae over a five year period arising from recurrent disease at separate sites in the gastrointestinal tract.

\section{Methods}

\section{PATIENTS}

The patients were divided into two groups. Group 1: no active disease. All were postoperative fistulae developing within one month of resection for Crohn's disease where there was no radiological evidence of recurrent or residual disease $(n=9)$. Group 2: active disease. (i) With no evidence of local abscess formation $(n=16)$. This group included five post-appendicectomy fistulae. (ii) Active disease with abscess formation confirmed at lapar-

Received for publication 19 July 1982 otomy $(n=14)$. It was often difficult to allocate patients to groups 2 (i) and 2 (ii) preoperatively as the diagnosis of intra-abdominal abscess was often only made at laparotomy (Table 1).

\section{CLINICAL PRESENTATION}

The clinical details are summarised in Table 2 . Postoperative fistulae were commoner in older patients with a long history of Crohn's disease. The post-appendicectomy fistulae occurred in younger patients where the diagnosis of Crohn's disease had not been made preoperatively. None of these fistulae arose from the appendix stump.

The high incidence of malnutrition in patients with fistulae, active disease and associated sepsis $(57 \%)$ was usually because of weight loss occurring after the fistula had developed (Table 2).

\section{ORIGIN OF THE FISTULAE}

The majority of fistulae arose from the ileum (Table 3).

The fistulae arising from other sites usually occurred spontaneously except for three patients with active disease and sepsis who had an intraabdominal abscess incised and drained, and who subsequently developed faecal fistulae. One other patient inserted a blunt object into his ileostomy stoma causing a traumatic perforation.

\section{DIAGNOSIS OF FISTULAE}

The presence of a fistula is usually obvious clinically and in all but four cases the connection between the 
Table 1 Details of patients

\begin{tabular}{lllll}
\hline Group & Type of fistula & $\begin{array}{l}\text { Patients } \\
\text { (no.) }\end{array}$ & $\begin{array}{l}\text { Fistulae at diagnosis } \\
\text { (no.) }\end{array}$ & $\begin{array}{l}\text { Duration of fistula } \\
\text { Crohn's disease } \\
\text { (yr) (range) } \\
(y r)(\text { range) }\end{array}$ \\
\hline 1 & $\begin{array}{l}\text { No active discase (postoperative fistulae) } \\
\text { Active disease } \\
\text { (i) Without abscess }\end{array}$ & $9(9$ women) & 9 & $50(39-70)$ \\
(ii) With abscess & $16(10$ men) & 16 & $34 \cdot 5(17-55)$ \\
\hline
\end{tabular}

gut lumen and skin was readily confirmed radiologically. A fistulogram can define the complexity of the fistula track and its connection with the gut lumen but the extent and severity of the underlying Crohn's disease is better shown by barium contrast studies.

Although the barium contrast studies often showed the site of origin of the fistula this could be identified more consistently and accurately by a fistulogram (Table 4).

\section{RESULTS OF MANAGEMENT}

1 No active disease Of the nine postoperative patients in this group, seven were treated expectantly with parenteral fluid and electrolyte replacement and antibiotics as indicated. One patient had total parenteral nutrition for two weeks, and two patients enteral feeding for one month. All had skin care by specially trained staff. Six healed within six weeks, and remained healed (mean follow-up 4.4 years, range $1.5-7 \cdot 5$ years). The seventh patient was treated by (possibly premature) operative closure after one month. Two patients were treated surgically; one patient with an enterocutaneous and enterovaginal fistula had an early elective resection and the other with disseminated malignant myeloma had a proximal ileostomy to facilitate terminal care (Table 5).

2 Enterocutaneous fistulae and active disease: medical management Twenty patients were treated with persistent conservative management (usually before referral) for a mean period of 19.8 months (range three weeks to nine years). Only one patient was treated for less than six weeks.

Medical management before referral included maintenance of fluid and electrolyte balance, replacement of blood loss, intensive nursing support with particular attention to peristomal skin care and often the use of corticosteroids or salazopyrin and in three patients azathioprine for at least two months. Five referred patients received parenteral nutrition for a minimum of six weeks, and a further three patients received a minimum of six weeks nasogastric tube feeding using elemental diets. Only one of these 20 fistulae closed.

\section{CONSERVATIVE SURGERY}

Eight fistulae (seven patients) were treated by conservative surgical means, in six cases by drainage of associated intra-abdominal sepsis and in two by diverting ileostomy, including one patient to facilitate terminal care (see above). One fistula, a colocutaneous fistula, closed after diverting ileostomy.

Table 2 Clinical presentation

\begin{tabular}{|c|c|c|c|c|c|c|c|c|c|c|c|}
\hline \multirow{2}{*}{\multicolumn{2}{|c|}{ Group }} & & \multicolumn{6}{|l|}{ Symptoms } & \multicolumn{3}{|c|}{ Investigations } \\
\hline & & & Discharge & Malaise & Pain & Fever & Diarrhoea & $\begin{array}{l}\text { Mal- } \\
\text { nutrition* }\end{array}$ & $\begin{array}{c}\text { Albumin } \\
<30 \mathrm{~g} / \mathrm{l}\end{array}$ & $\begin{array}{l}\text { Oroso- } \\
\text { mucoids } \\
>1.2 \mathrm{~g} / \mathrm{l}\end{array}$ & $\begin{array}{c}E S R \\
>25\end{array}$ \\
\hline 1 & No active disease & $\begin{array}{l}\mathbf{N} \\
\%\end{array}$ & $\begin{array}{l}9 \\
(100)\end{array}$ & $\begin{array}{l}1 \\
(11)\end{array}$ & $\begin{array}{l}2 \\
(22)\end{array}$ & 0 & 0 & $\begin{array}{l}3 \\
(33)\end{array}$ & 0 & $\begin{array}{l}5 \\
(55)\end{array}$ & $\begin{array}{l}5 \\
(55)\end{array}$ \\
\hline 2 & $\begin{array}{l}\text { Active disease } \\
\text { (i) Without abscess } \\
\text { (ii) With abscess }\end{array}$ & $\begin{array}{l}\mathbf{N} \\
\% \\
\mathbf{N} \\
\%\end{array}$ & $\begin{array}{l}16 \\
(100) \\
14 \\
(100)\end{array}$ & $\begin{array}{l}8 \\
(50) \\
9 \\
(64)\end{array}$ & $\begin{array}{l}5 \\
(31) \\
10 \\
(71 \cdot 4)\end{array}$ & $\begin{array}{l}5 \\
(31) \\
7 \\
(50)\end{array}$ & $\begin{array}{l}2 \\
(12) \\
7 \\
(50)\end{array}$ & $\begin{array}{l}1 \\
(6) \\
8 \\
(57)\end{array}$ & $\begin{array}{l}7 \\
(43) \\
9 \\
(64)\end{array}$ & $\begin{array}{l}11 \\
(64) \\
12 \\
(85 \cdot 7)\end{array}$ & $\begin{array}{l}10 \\
(53) \\
8 \\
(57)\end{array}$ \\
\hline
\end{tabular}

* Malnutrition in this study defined as weight loss of $>10 \%$ of normal body weight. 
Table 3 Origina of fistula

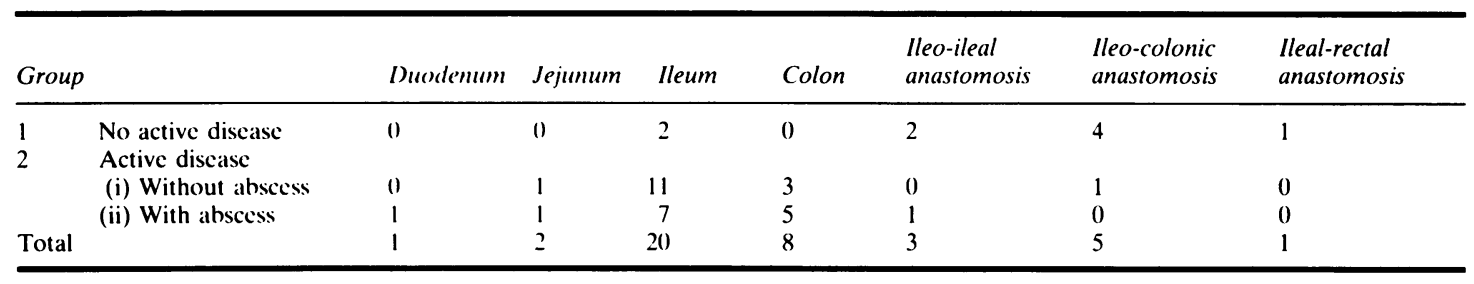

\section{SURGICAL EXCISION}

Resection of the diseased bowel at the origin of the fistula together with any distal obstruction was undertaken after the failure of medical treatment in 19 patients and as the treatment of choice in 10 patients, and was successful in all but one (Table 6). The mean duration of stay after resection was 18.9 days (range seven to 70 days). No fistula has recurred after resection. The mean interval since resection is 4.6 years (range nine months to 10 years).

There was one fistula related death in a 24 year old man with a self-induced traumatic ileal fistula which had been oversewn. When referred there were recurrent fistulae with extensive abdominal sepsis and severe metabolic problems. He died of a pulmonary embolus after further surgical treatment.

\section{Discussion}

The principles of management of enterocutaneous fistulae in conditions other than Crohn's disease are well described. ${ }^{6-16}$ These include the treatment of sepsis, nutritional and metabolic support, skin care, and surgical intervention to relieve distal obstruction.

The optimal management of fistulae in patients with Crohn's disease is debated. Individual series of patients with Crohn's disease usually include few patients with enterocutaneous fistulae, ${ }^{117}$ while series describing enterocutaneous fistulae only include a few patients with Crohn's disease. ${ }^{11} 12$ Early operation with resection of the diseased bowel and any distal obstruction has been advocated ${ }^{12}$ though an aggressive surgical policy of resection in Crohn's disease could cause a short bowel syndrome. ${ }^{18}$ Claims have been made that parenteral nutrition and 'bowel rest' can induce spontaneous closure in up to $50 \%$ of enterocutaneous fistulae ${ }^{35}$ but the validity of these claims has been challenged. $^{12} 1920$

Because our analysis includes many referred patients we have been able to review the results of varied approaches to management. The presence of fistula is usually obvious clinically but can be readily confirmed with a fistulogram.

Postoperative fistulae (mainly anasomotic leaks) where there is no radiological evidence of recurrent or residual Crohn's disease or distal obstruction must be distinguished from fistulae associated with radiological evidence of recurrent or residual disease.

Postoperative fistulae will usually heal spontaneously with conservative measures alone. The inclusion of such patients in any study of 'specific' treatment could clearly produce apparently favourable but misleading results.

Attempts to close enterocutaneous fistulae secondary to residual or recurrent Crohn's disease which may be associated with local sepsis with specific medical treatment (salazopyrin, corticosteroids and azathioprine) or total parenteral nutrition in this series have been unsuccessful. These attempts have been associated with long delays before curative surgical resection has been undertaken.

Our results suggest that patients with enterocutaneous fistulae and active Crohn's disease can be

Table 4 Radiological identification of enterocutaneous fistulae

\begin{tabular}{lllll}
\hline & $\begin{array}{l}\text { Number of } \\
\text { examinations }\end{array}$ & $\begin{array}{l}\text { Fistula } \\
\text { identified }\end{array}$ & $\begin{array}{l}\text { Suggestive of } \\
\text { fistula formation }\end{array}$ & Not shown \\
\hline Fistulogram & 26 & 24 & 1 & 1 \\
Barium contrast examination & 46 & 30 & 10 & 6 \\
\hline
\end{tabular}


Table 5 Outcome of medical treatment of enterocutaneous fistulae

\begin{tabular}{|c|c|c|c|c|c|}
\hline & \multirow[b]{2}{*}{ Fistula } & \multirow[b]{2}{*}{ Total treated } & \multirow{2}{*}{$\begin{array}{l}\text { Mean duration } \\
\text { of treatment (range) }\end{array}$} & \multicolumn{2}{|c|}{ Outcome } \\
\hline & & & & Closed & Persisted \\
\hline 1 & No active disease & 7 & $\begin{array}{l}6 \text { wecks } \\
(2 / 52-12 / 52)\end{array}$ & 6 & $\begin{array}{l}1 \\
(1 / 12)\end{array}$ \\
\hline 2 & Active disease & 20 & $\begin{array}{l}19.8 \text { months } \\
(3 / 52-9 \text { ycars })\end{array}$ & $\begin{array}{l}1 \\
(11 / 12)\end{array}$ & 19 \\
\hline
\end{tabular}

treated effectively and restored rapidly to good health by excision of the disease bowel and any distal obstruction. Only the grossly abnormal bowel need be resected. Even when there is mucosal abnormality at the line of resection, anastomosis has proved safe provided there is no residual distal obstruction. ${ }^{21}$

Table 6 Surgical treatment of enterocutaneous fistulae

\begin{tabular}{|c|c|c|c|c|}
\hline \multirow[b]{2}{*}{ Procedure } & \multirow{2}{*}{$\begin{array}{l}\text { Number of } \\
\text { operations }\end{array}$} & \multicolumn{3}{|c|}{ Outcome } \\
\hline & & Closed & Persisted & Died \\
\hline $\begin{array}{l}\text { Conservative } \\
\text { (7 patients) }\end{array}$ & 8 & 1 & 7 & - \\
\hline $\begin{array}{l}\text { 'Curative' } \\
\text { (29 patients) }\end{array}$ & 29 & 28 & - & 1 \\
\hline
\end{tabular}

\section{References}

1 Enker WE, Block GE. The operative treatment of Crohn's disease complicated by fistulae. Arch Surg 1969 98: 493-9.

2 Steinberg DM, Cooke WT, Alexander-Williams J. Abscess and fistulae in Crohn's disease. Gut 1973 14: 865-9.

3 Greenberg GR, Hisher GB, Jeejeebhoy KN. Total parenteral nutrition and bowel rest in the management of Crohn's disease. Gut 1976 17: 828.

4 Driscoll RH Jr, Rosenberg IH. Total parenteral nutrition in inflammatory bowel disease. Med Clin $N$ Am 1978 62: 185-201.

5 Muller JL, Hargrave WC, Dudrick SJ, Fitts WT Jr, Rosata EF. Ten years experience with intravenous hyperalimentation and inflammatory bowel disease. Ann Surg 1978 187: 523-9.
6 Sheldon GF, Gardiner BN, Way LW, Dunphy JE. Management of gastrointestinal fistulac. Surg Gynecol Obstet 1971 133: 385-9.

7 Roback SA. Nicoloff DM. High output enterocutaneous fistulac of the small bowel. Am J Surg 1972 123: $317-22$.

8 MacFadyon BV, Dudrick SJ, Ruberg RL. Management of gastrointestinal fistulae with parenteral hyperalimentation. Surgery 1973 74: 100-5.

9 Irving M. Local and surgical management of enterocutaneous fistulae. Br J Surg 1977 64: 690-4.

10 Monod-Broca P. Treatment of intestinal fistula. $\mathrm{Br} J$ Surg 1977 64: 685-9.

11 Blackett RL, Hill GL. Post-operative external small bowel fistulae: a study of a consecutive series of patients treated with intravenous hyperalimentation. Br J Surg 1978 65: 775-8.

12 Rober HA, Robert C, Way LW, Dumphy JE. Management of external gastrointestinal fistulas. Ann Surg 1978 188: 460-7.

13 Sternguist JC, Bubrick MP, Hitchcock CR. Enterocutaneous fistula. Dis Colon Rectum 1978 21: 578-81.

14 Coutsoftides T, Fiezio VW. Small intestine cutaneous fistulas. Surg Gynecol Obstet 1979 149: 333-6.

15 Soeters PB, Elerd AM, Fischer JE. Review of 404 patients with gastrointestinal fistulas. Ann Surg 1979 190: $189-202$.

16 Alexander-Williams $\mathrm{J}$, Irving $\mathrm{M}$. Intestinal fistulas. Bristol: Wright, 1982

17 Eisenberg HW, Turnbull RB, Weakley FL. Hyperalimentation as preparation for surgery in transmural colitis (Crohn's disease). Dis Colon Rectum 1974 17: 469-75.

18 Reilly J, Ryan JA, Stroke W, Fischer JE. Hyperalimentation in inflammatory bowel disease. Am J Surg 1976 131: 192-200.

19 Elson CO, Layden TJ, Nemchousky BA, Rosenberg JL, Rosenberg IH. An evaluation of total parenteral nutrition in the management of inflammatory bowel disease. Dig Dis Sci 1980 25: 42-48.

20 Rosenberg IH. Nutritional support in inflammatory bowel disease. Gastroenterology 1979 77: 393-6.

21 Pennington L, Hamilton SR, Bayless TM, Cameron JL. Surgical management of Crohn's disease. Influence of disease at margin of resection. Ann Surg 1980 192: 311-8. 